\title{
The Place of Rule of Law in Iran
}

\author{
Maryam Ameri ${ }^{1, *}$, Hadiyeh Sadat Mirtorabi ${ }^{1}$ \\ Department of Law, Payame Noor University, PO BOX 19395 - 3697, Tehran, Iran \\ *E-mail address: Maryamameri80@yahoo.com
}

\begin{abstract}
Harassing the power and its reflection in the history of law is the result of the elders' efforts and sacrifices along with the insights of the rulers and revolutionaries whose names may have never been cited but their great efforts are always being discussed and underpins large scale developments. Specifically, this article has discussed the process of law formation in Iran with an emphasis on Constitutional Revolution (known as constitutionality) and Constitutional movement delimiting and regulating power, controllingautocracy and unconditionality and covering the rule of law and good governance in brief.
\end{abstract}

Keyword: Constitutional revolutionaries; constitutionality; separation of powers; National Assembly

\section{INTRODUCTION}

Today the rule of law is of high status and dignity. This is so important that after 2500 years from the government of ancient Greek cities, this concept has developed in philosophical, political and legal fields along with academic and political circles of the world and the experts are analyzing and researching in regard with its implications, features and effects.

They try to present new perceptions by reflecting on the concept of rule of law so that it is suitable for the current social, political and economic situation. Furthermore, today along with the development of concept of global democracy, global justice and global citizenship, the rule of universal law is talked about in order to cover the formation of international institutions and global organizations responsible for maintaining international order and security like International Crime Court (ICC) to put an end to the phenomenon of internationally described criminal impunity. While the theory of rule of law is a relative concept and no country can claim to fully implement the Law and regulations, it is also almost accepted by most scholars.

According to the theory of rule of law, all actions should be done in accordance with the rules and regulations, the law and sanction of its violation must be enforced by the competent authorities, a competence which is enacted by the law and its limit is determined. In the theory of rule of law, equality, brotherhood, human rights, justice, freedom (according to the law), are among the objectives. In other words, all these cases pave the way for the rule of law. 


\section{THE PROCESS OF LAW FORMATION AND THE RULE OF LAW IN IRAN}

Before Constitution (Mashrootiat), at least until the end of the reign of Naseroddin Shah there was no law. Whatever there was, it was religion which was used in in the interests of then governments. Excessive and severe punishments, acceleration in carrying out trial and punishment and lack of adequate accuracy were among the features of trial of that time. Generally, religion and its articles were forgotten in this period and/or they were interpreted in the interest of someone.

Moreover, only the king and/or other elders could interfere as the power of regulation in cases identified by them and prevent from carrying out punishment. After Constitutional Revolution, physical and mental preparation appeared to accept new fundamentals. Constitution dated December 30, 1906 and its amendment in October 7, 1907 revolutionized the political, social and cultural structure of Iran. However, the foundation of justice was delayed due to the opposition of the clerics who considered just Sharia competent to investigate.

Following the formation of religious government, many (criminal) laws went under changes. Given that this time the clerics tried to use customary law while adhering to religious law which was outdated as they believed. Therefore, many old laws remained intact since they were not in conflict with Sharia law and they were corroborated to be enforced. Meanwhile, new laws compatible with Sharia law were also approved. Before the revolution, it was the government which was not legitimate and thus it was considered as the people's enemy.

But after the revolution and within "The Islamic Ummah" and "Islamic rule" it is not the government which is illegitimate, but the people must be competent enough to live in the Islamic Ummah. Thus, the people became the immediate enemy of the government (Veysi, 2003).

\section{CONSTITUTIONAL REVOLUTION AS THE TURNING POINT IN THE LAW FORMATION IN IRAN}

Freedom and equality were also the most important issue in the process of modernism movement in Iran In the late $19^{\text {th }}$ century, which was a problem for the traditionalists and the opponents of the movement. Imaging a society based on freedom and equality which was promised by the modernists was difficult for the traditionalists.

In the early $20^{\text {th }}$ century after Constitutional revolution and when Iranians imitated French Revolution in revising relations between the government and the nation and tried to found a government compatible with the new era requirements, freedom and equality was really controversial at the time and its reflection in the articles of Constitution led to a widespread struggles between the proponents and opponents (Movahed, 2005).

The main objective of Constitution was to restrict and limit it to the law and to release the country from the domination of foreign forces. To achieve this goal, it was necessary to go after ideas like Constitution, law and an integrated political system along with the strong and efficient central government, which provided the means to develop the country's economy and politics. Constitution movement could familiarize the people with the discourse of power and build the structure of power based on three components of people, law and religion. Therefore, Constitutional revolution is regarded as a turning point in the history of rule of law development, pushing back the limits of traditional discourse of power to a great extent and building the structure of power on a new basis. 


\section{THE FORMATION AND CODIFICATION OF MASHROOTEH CONSTITUTION}

Mashrooteh Constitution and its amendment. It is of high importance to examine Mashrooteh Constitution and its amendment in all respects. At least, it makes us aware of revolutionaries' demands. This law was codified and approved in 158 articles (Constitution with 51 articles and its amendment with 107 articles) in two stages.

One of the notable things in regard with the history of Iran was that for the first time monarchy became terrestrial. According to amendment 35, "Monarchy is a deposit as a gift from God delegated by the people to the king".

Although monarchy was still a divine gift, it was the "people" who delegate this duty and position. According to article 11 of Constitution and articles 1 and 58 cited in amendment of Constitution, belief in Islam and being religious were mentioned for the authorities. Articles 2 and 27 in amendment had regulated the influence of religion through a 5 member board including mujtaheds for there was no conflict between Majlis and Islamic laws. Articles 8-25 in amendment of Constitution had mentioned people's rights. In fact, for the first time ever people's rights, people power, people sovereignty and unlimited rejection and freedoms were included in the Constitution (Veysi, 2003).

However, this law had some defects. Mashrootiat Constitution and its amendment lack logical order in its chapters and articles and as a result there are apparent contradictions in some cases. For example, national ownership rights cited in article 26 in Constitution amendment is in conflict with monarchy rights cited in articles 35-55. As a matter of fact, the most prominent conflict is concerns the principle of separation of powers. On the other hand, in article 27 cited in amendment of Constitution, both legislature and executive are identified as specific domain of the king while just the next article emphasizes the separation among three branches.

The most important problem concerning Constitution may be that no one or institution has not been allowed to interpret the Constitution. Although article 27 of the amendment has determined National Assembly as specifically responsible for interpreting the laws, it has not clarified what it means by the interpretation of ordinary laws passed by the parliament and whether Constitution and its amendment are included or not.

\section{FACTORS AFFECTING THE FAILURE OF MASHROOTEH}

The second period of Mashrooteh is an important one in the contemporary history of Iran. This period began by the conquest of Tehran by the Constitutionalists and of course foreign forces in Iran played a key role in Mashrooteh. The problems and obstacles made as a result of foreign forces' performance in Iran against Mashrooteh played such a key role that it can even be claimed that the role of Mashrooteh' foreign factor was much more important than that domestic factors in the final analysis. Since 1965 when Constitutional Revolution took place until 1978 when Islamic Revolution brought a new system into power in Iran, the political system of Iran was apparently constitutional. There was a parliament and law as well but there was no limit applied on the power of government, no representative of the nation in the parliament and no significant rule of law (Zibakalam, 1998). 


\section{THE PLACE OF LAW IN IRAN IN 1978 AND THE CURRENT APPROACH}

After Islamic Revolution, a dramatic event occurred which was very important from the development of government-nation viewpoint. After this revolution, Shiite clergy took the control of the government and by establishing the principle of divine (spirituality), it recognizes the rule not for the nation but the Islamic nation. Therefore, there has emerged a fundamental conflict between government-nation currently in Iran and the rule of Islamic Nation, which leads to more discontinuity between nation and government. After the revolution, there appeared a dual space in legal terms and regarding realities.

Structurally, the structure of Islamic Republic of Iran's Constitution like some old mixed Constitutions is a mixture of different components such as selective autocracy, aristocracy and oligarchy (clerical class) and democracy (direct elections of the President and parliament). The Leader supervises the three branches of the government and plays the main role inthe political system. After the revolution (or return to traditionalism), not the government or a special party or class but the Islamic tradition (that is interpreted by the clerics) shall be respected. All rights, duties and values are embedded in the Islamic tradition context and one is given the rights and values just in this context. Before 2007 Islamic Republic was an ideological government but after that some Islamic Republic's democratic potentials became more active. Generally, what has happened during the rule of Islamic Republic has been a transition from an ideological government in the early years of the revolution to a kind of formal democracy, then toward a kind of pseudo democracy and formal or flashy democracy refers to a kind of oligarchy in which there are some formal or flashy democratic institutions. In this kind of democracy, traditional oligarchs govern the organizations and formal forms of democracy and until these organizations and forms act as a cover for the rule of oligarchs, formal democracy continues.

Among the features of such a democracy in Iran before 1997 are as follows: the establishment of some basic processes and institutions but used to cover the power of oligarchs, the importance of clerics' dignity as the most organized political class in formal democracy, the role and special place of clerics in controlling legislative institutions, executive and judiciary, the secondary role of parliament and elections as a national symbol against the main place of velayat-e faqih (also known as Islamic Government) and the authority of clerics as the manifestation of divine sovereignty, the instrumental nature of democratic institutions in stabilizing the foundation of system, restrictions on civil and political liberties to protect the core principles of Islamic rule.

After the elections 1997, a variety of trends such as the rule of law, civil society, democracy and political reforms developed in the society but as it is apparent after that time the rule of law and political development faced serious challenges some of which are presenting extralegal interpretations of velayat-e faqih, the serious appearance of plainclothes policemen in the political arena of Iran, widespread supervisory approval by the Guardian Council and many other cases. On the other hand, after the rule of Islamic laws or Sharia, it was not the law which should have adapted itself with the society's requirements but it was the community which should have adapted itself with the pre-established rules. This is specifically more evident in regard with criminal laws (retaliation). 


\section{THE RULE OF LAW AND MASHROOTIAT}

After dealing with Mashrootiat (Constitution) and the stages of its formation in brief, it is necessary to talk about the relationship between the rule of law and Mashrootiat (Constitution):

The word "Constitution" is derived "to constitute" meaning to form, found which itself is derived the Latin root "constituere" meaning the same. Lexically, what is held is founded and as a result its content can be called Constitution. The objective of Constitutional government is to delimit the structure of power and framework of rulers' authority (Zibakalam, 1998). And as behavioral politics of the rulers advances, the framework and cover of Constitution changes and develops with a completely different theme and content. However, the relationship between Constitution and the rule of law depends on our perceptions and definitions although these two words are in common historically. In this regard, it can be claimed that Constitutional government plays the key role in the rule of law and the presence of Constitutional government can ensure the enforcement and protection of substantive and procedural justice and regulate the relationship between the individual rule and the rule of law. As a result, the support and insurance which is done on the part of Constitutional government reaches such a development and institutionalization that protects the enforcement and development of the rule of law itself.

As we know, the primary meaning of rule of law is restriction. It delimits the performance and the range of government's activities and requires that the government move in the predetermined way. Now there is a question as how these restrictions are placed? And the answer is again related to the legal structures and specific sanctions. The principle of separation of powers, judicial supervision and independence of judges are some examples of placing these restrictions. Here Constitutionacts as the center of gravity and an effective and efficient system and brings it capability into existence since Constitutional government is also based on the superiority of Constitutions, the separation of powers and judicial independence.

Constitutional systems' objective is the rule of law and a legal government not a group of people and acts upon the law or rule in addition to liberty (Neumann, 2011). Without the rule of law, there is no Constitutional government. This means that the appearance of sole authority of legislator in codifying the laws results in a meaninglessness ofthe Constitutional government since legal structures, the separation of powers, judicial control and the insurance of peoples' rights require some restrictions on decisions made by the legislator and such restrictions are enacted by the rule of law, completed and carried out by an independent judiciary. It should be noted that the realization of the rule of law requires the existence of some conditions paving the way for its development and one of the most prominent ones is the existence of a democratic government. The democratic government is taken from the word "democracy" its root being in ancient Greece (Mill, 1990).

Democracy is one of the many forms of the rule in which the decisive and fateful role of the people in the political, social and economic future of the country is recognized and it is a regime in which pluralism, the freedom of parties and groups, freedom of speech and expression and the rotation of political power are paramount peacefully. This kind of system aims to provide the minimum public interests and it is shown in the demands of those ruled in modern Constitutions (Alam, 1998). Democracy has various conditions and each one has a different degree and the proposing any theory of democracy, environmental law, political life and maintaining each theory depends on the conditions and social issues specific to that community. In the end, it is concluded that the existence of economic prosperity to some degree is a necessary condition of democracy (Cohen, 1994). 


\section{CONCLUSION}

The process of rule of law in all societies has a history. In this regard, this country (Iran) was no exception and as it was examined, there have been many ups and downs in controlling the power and authorities. Freedom, equality and basic rights are some components and principles of rule of law. Ignoring any of them leads the system to dictatorship and autocracy and results but in collapse.

\section{References}

[1] Veysi H. (2003). Obstacles to the realization of the rule of law in Iran. Tehran: Tehran University publications.

[2] Movahed M. A. (2005). The air of truth and justice. Tehran: Karnameh publications.

[3] Zibakalam S. (1998). Tradition and modernism. Tehran: Rozaneh publications.

[4] Neumann F. (2011). Freedom and the power of law. Translated by Ezotollah Fooladvand. Tehran: Kharazmi publications.

[5] Mill J. S. (1990). Reflections on the selected government. Translated by Ali Ramin. Tehran: Nay publications.

[6] Alam A. (1998). The fundamentals of political science. Tehran: Nay publications.

[7] Cohen C. (1994). Democracy. Translated by FariborzMajidi. Tehran: Kharazmi publications.

[8] Askar Jalalian, Zohreh Moradi, International Letters of Social and Humanistic Sciences 19 (2014) 1-7. 